\title{
Contradiction Is Not Disappointing: An Interview with Michael Hardt
}

\section{Helena Feder}

To cite this article: Helena Feder (2019): Contradiction Is Not Disappointing: An Interview with Michael Hardt, Capitalism Nature Socialism, DOI: 10.1080/10455752.2019.1656272

To link to this article: https://doi.org/10.1080/10455752.2019.1656272

册 Published online: 19 Aug 2019.

Submit your article to this journal

Џ Article views: 29

Q View related articles $\asymp$

View Crossmark data \lceil 
Interview

Check for updates

\title{
Contradiction Is Not Disappointing: An Interview with Michael Hardt
}

\author{
Helena Feder
}

Department of English, East Carolina University, Greenville, NC, USA

Michael Hardt is a theorist whose work examines philosophical and material forms of domination and forces of liberation. In the internationally acclaimed Empire books - Empire (2000), Multitude (2004), Commonwealth (2009), Declaration (pamphlet, 2012) and, most recently, Assembly (2017) - Hardt and co-author Antonio Negri theorize the economic, political, and social aspects of globalization. In Multitude Hardt and Negri continue to discuss various incarnations of Empire, such as the annual meeting of power in Davos, Switzerland:

The most important lesson to learn from Davos is simply that such a meeting is necessary: the economic, political, and bureaucratic elites of the world need to work together in constant relation. In more general terms, it demonstrates the old lesson that no economic market can exist without political order and regulation. If by free market one means a market that is autonomous and spontaneous, free from political controls, then there is no such thing as a free market at all. (Hardt and Negri 2004, 167)

In "The Common in Communism," published a year after Commonwealth, Hardt extends this thought:

Many central concepts of our political vocabulary, including communism as well as democracy and freedom, have been so corrupted that they are almost unusable. In standard usage, in fact, communism has come to mean its opposite, that is, total state control of economic and social life. We could abandon these terms and invent new ones, of course, but we would leave behind too the long history of struggles, dreams and aspirations that are tied to them. I think it is better to fight over the concepts themselves in order to restore or renew their meaning. $(2010,131)$

And that is exactly what Hardt does, fighting for the common of the political imaginary. As Jacques Rancière suggests, what is at stake in such key terms is the definition of politics itself: "a struggle about what politics is, a struggle that is waged about such original issues as: 'where are we?,' 'who are we?,' 'What makes us a we,' 'what do we see and what can we say about it that makes us a 
'we,' having a world in common?"' (116). Indeed, we are all part of a common world, and one that continues to change rapidly, socially and ecologically, for the immediate benefit of some at the expense of a great many others. And yet, as Hardt and Negri argue, the ground on which Empire and Multitude confront each other is the Common, a web of relations material and immaterial, ordinary and affective, mutable and enduring.

Against the false transcendence of power we find love as the emergent property of multiplicity. In Commonwealth Hardt and Negri assert: "Love is an ontological event in that it marks a rupture with what exists and the creation of the new. Being is constituted by love" $(2009,181)$. Hardt's recent work continues to develop a "political concept of love," which would:

reorient our political discourses and practices in two important ways. First, it would challenge conventional conceptions that separate the logic of political interests from our affective lives and opposes political reason to the passions ... [It] would have to deploy at once reason and passion. Second, love is a motor of transformation and duration or continuity. We lose ourselves in love and open the possibility of a new world, but at the same time love constitutes powerful bonds that last. $(2009,676)$

The object of this idea is "to understand how love can be the central, constitutive mode and motor of politics" (2012b, 161).

In "The Power to be Affected" Hardt enacts just such a concept when he argues,

Whereas the sovereign subject is (or imagines itself to be) impervious to and unmoved by external forces, and whereas projects aimed at sovereignty strive to minimize the influence of others, we should conceive being affected by others as a virtue. The most powerful is not the one least affected, but, on the contrary, the one affected the most and in the most ways. The more you are affected in many ways, the more alive you are, and to the extent you cease to be affected, to the extent you close off from the world, that much you die. $(2015,217)$

This turn to love is part of Hardt's overall project to, from Empire on, articulate the ways in which economic logics are "embedded in the political and cultural" and "fundamentally concerned with struggles over modes of the production of subjectivity and forms of life" (2012a, 374). This is, one might argue, also the fundamental project of critique, which moves between and beyond disciplines (and other modes of the production of subjectivity) to investigate humanism's multiple relations to itself and its others, to domination and liberation.

Hardt and I met in his office at Duke University, where he is Professor and Chair of the Literature Department, to discuss his work, recent events, and remarks made at a conference held at Duke that weekend, moderated by Fredric Jameson (1979) and featuring talks by Slavoj Žižek, Alenka Zupančič, and Mladen Dolar. ${ }^{1}$ Zupančič gave two wonderful talks, entitled "Apocalypse 
is Disappointing" (on Blanchot's essay of the same title) (Blanchot 1997) and "Sex is Disappointing" (on Freud, Lacan, and the death drive); apologies to Zupančič for my title, and thanks to Hardt for a wonderfully engaging hour. We discuss many aspects of his work and how it connects to environmental thought through the concept of the common (particularly at the end).

$\begin{array}{ll}\text { Helena Feder: } & \text { Slavoj Žižek concluded the second of his talks here at Duke } \\ & \text { with an inversion of Marx's eleventh Theses on Feuerbach. } \\ \text { What do you think of Žižek's claim (which he's made } \\ \text { before) that perhaps we changed the world to fast? He } \\ \text { argues that our goal now should not be to change the } \\ \text { world but to spend more time interpreting it - or to interpret } \\ \text { it better. } \\ \text { Michael Hardt: } \\ \text { The importance of the eleventh thesis is really not to dismiss } \\ \text { the former and affirm the latter, but to say that both are } \\ \text { necessary. So, I don't really see the point in inverting it. I } \\ \text { would not say, of course, that the world doesn't need to } \\ \text { change (sorry for the double negative). One also needs to } \\ \text { interpret it, of course. In fact, the way we change it ought } \\ \text { to be informed by the way we interpret it. So, maybe that's } \\ \text { the way to approach the eleventh thesis. And that's probably } \\ \text { what Žižek is getting at too. } \\ \text { As an affirmation of praxis? } \\ \text { An affirmation of praxis, if by praxis you mean that social } \\ \text { change that is constantly informed by a critical attitude. } \\ \text { And what do you make of Žižek's general charge that Marx is } \\ \text { too idealistic? } \\ \text { In The Parallax View (2006) Slavoj criticizes Toni Negri and } \\ \text { me for making the same mistakes that Marx makes, which is } \\ \text { MH: } \\ \text { to believe that capitalist development provides the tools for } \\ \text { its own overthrow. What he is concerned about, it seems } \\ \text { to me (and this part is certainly right), is the belief that capi- } \\ \text { talist development automatically generates its own over- } \\ \text { throw and inevitably leads to a better social formation. } \\ \text { MH: } \\ \text { Capitalist development does provide the opportunity and } \\ \text { tools for its transformation, but there's nothing automatic } \\ \text { about it. It requires subjective intervention, requires organiz- } \\ \text { ation, etc. Toni and I are very happy to be lumped together } \\ \text { with Marx in that respect. }\end{array}$

I should put it this way: What Toni and I are struggling against is a notion of anti-capitalism that refuses or rejects wholesale all that belongs to capital, that thinking of anti-capitalism as external, as being outside of it or, in some way, as pure from it.

HF: As Marx says, there's no innocence within capitalism; no "pure" position from which to critique it...

\footnotetext{
1"Contradictions that Matter: Sex, Ontology, and Apocalypse," April 11-13, 2018.

2"Ernst Lubitsch II: Cynicism, Humor, and Engagement," April 13, 2018.
} 
MH: That seems like a nice way of saying what Toni and I argue. This is a slogan that predates me in the Italian tradition of "operaismo," a slogan from the 1960s: We have to be within and against. Being within doesn't preclude being against. The most powerful challenges are really the ones born from the inside (and there is no purity, though this seems like it should be an obvious point). I do think it's important to recognize the ways in which capitalist development provides tools for constructing an alternative and better social formation.

HF: You've argued in many places that some concepts are worth fighting for, that this sort of battle is "one of the central tasks of political thought” (Hardt and Negri 2017, xix). You've discussed the potential dangers of intellectuals "becoming public" (2017, 12), but I take it that this is the kind of work intellectuals must do in public for the public good - fighting for such concepts?

$\mathrm{MH}$ : Sure. What we're critical of is the notion of the public intellectual as a kind of leader in thought, that the public intellectual is the one whom activists need to follow. Think of Adorno and Habermas in Frankfurt in 1968 - they had divergent views but both positioned themselves as public intellectuals to rein in, critique, or guide the movements. It's that image of the public intellectual that we're resisting. Maybe we should argue for "the social intellectual," one socially engaged, but not in order to teach the ignorant masses what they ought to think. Part of the role of intellectuals is to learn from types of knowledge and intellectual activity created in other contexts, in movements and places outside the university.

HF: The phrase "social intellectual" might be great for your purposes. As long as you've mentioned him, can we discuss Adorno for a moment? What do you think of Adorno's fundamental insight - the recognition of culture's recursive and often-invisible role in the internalization of oppression?

$\mathrm{MH}$ : Certainly, the recognition of affects and subjectivity as central to politics (pulling a notion of politics away from traditional conceptions of interests and reason) seems absolutely fundamental to me. One primary point on which Toni and I part from him regards subjectivity: for Adorno and Horkheimer both, capital has so completely subsumed society as a whole that all subjectivity tends to be capitalist subjectivity - produced by capital. That leads them to a certain suspicion, if not negation, of the possibility of autonomous subjectivities of the German working class. The working class is almost by necessity (in their logic) bound up with capitalist subjectivity and so can't be the source of a critique of or an alternative to capitalism. Whereas, for Toni and me, it's extremely important to recognize the relatively autonomous productions of subjectivity within capitalist society, even within the relation with capital.

HF: I get the impression from your work that you think Adorno's not useful, as opposed to simply wrong.

$\mathrm{MH}$ : Not useful to us, I suppose, and perhaps due to some lacking on our part. We have a different source of that same thought, and I wonder how the difference leads in different directions. In the beginning of his Theological-Political Treatise Spinoza (2007) asks, "Why is it that 
some people strive for their servitude as if it were their liberation?" This seems to me fundamentally the same thought that you paraphrased from Horkheimer and Adorno's Dialectic of Enlightenment (2002).

HF: You've said in many contexts that you're incredibly optimistic; one might even say your work constructs a politics of optimism. Do you ever find popular culture in capitalism disheartening?

$\mathrm{MH}$ : Sure, yeah, of course ... I've become rather sensitive to being called an optimist. It seems that when people call you an optimist they mean it as an insult - as if you are so naive as to believe (with no reason) that things will get better, that you are so clueless that you don't recognize the weight and power and complexity of the forces that oppress us, that you lack the critical faculty to understand how terrible things are. But I know that's not what you mean.

Regarding popular culture, and as we've been discussing Adorno, I am reminded of a brilliant set up in Fred MacPherson's 1962 essay "Reification and Utopia in Mass Culture." He starts out by both affirming and criticizing the Adorno approach to capitalist or popular culture, which is that since it's commodified, it really involves reification and further reification of spirit, of culture, etc. Jameson argues that that's a crucial insight not sufficient for reading popular culture. One also has to recognize what he calls utopian moments or alternative visions of non-capitalist futures. So, an analytical method for reading popular culture must negotiate some relationship between the two.

HF: I think this makes sense if you're thinking of one of Raymond Chandler's novels or various works of science fiction. But can corporatecreated culture (which is most of popular culture: television, Hollywood movies, online games, virtual realities, etc.) reveal what ideology hides (as Adorno argued for art)?

$\mathrm{MH}$ : Fred was saying rather than just affirming something because it's popular and of the people or denigrating it because it's commodified, we need a way of discerning the different elements within these texts, elements of reification and utopia. This is related to what we were talking about before, about Marx's error of believing that capital in its own development provides the tools for its own overthrow. The majority of popular culture, of course, communicates capitalist values or is some way imbued with capitalist social relations, but that doesn't preclude the possibility that it also carries within it the potential for alternatives and change.

HF: Then you think of popular culture the way you think of technology: tools that carry open potential?

MH: Yes, that's right. That's what I liked about one of our epigraphs in Empire, the last line of a song by Ani DiFranco (2017): "Every tool is a weapon/If you hold it right."

HF: Can we separate the culture industry and the manufacture of political consent from what we could (and probably should) call the Information-Technology-Military-Industrial-Complex? 
MH: It's very important to recognize how military logics and military technologies (especially in the U.S., but also elsewhere) completely permeate other realms of techno-social worlds. I think that we must recognize this logic to oppose those aspects of technology. But this is another case in which I wouldn't disregard such technologies because they are impure.

It's true that, for instance, military recruiters use video games and video technologies to get young people to enlist, or you can even think of it on a broader scale: that there are a variety of video games that just train the population for a military mindset. So, would you then say, "Well, all video games should be opposed because they're military?"

HF: Yes, that might be a more radical position to take than, "Well, Pac-Man is okay but first-person shooter games aren't." Cognitively and politically, they might pose similar enough problems (however much I once enjoyed Pac-Man).

$\mathrm{MH}$ : There certainly are problems, but I wouldn't even try to adjudicate this. I think that one can oppose and find valuable things in them at the same time. The value of technology shouldn't be determined by its source. For instance, how many times have you heard people recount how the internet was really started by DARPA (Defense Advanced Research Projects Agency). Should our attitude toward its subsequent development be determined by that origin? It's a leading question. It seems to me clearly not.

HF: Actually, it might be a genuine question. It seems to me that a genuinely critical view of culture should at the very least be informed by that origin.

MH: Then how about the formal analogy argument? Like this: capital functions as a network, as a decentered, distributed network - it functions in terms of multiplicities.

HF: But it also functions through the centralization of power.

$\mathrm{MH}$ : It partly does, too.

HF: And it centralizes power by increasing levels of integration, just like information technology.

MH: Yes. To return to one of Slavoj's talks, I remember from some years ago how he argued against the politics of multiplicity proposed by various poststructuralist thinkers (Deleuze and Guattari, in particular) by saying that capital too is really all about the proliferation of multiplicities and the celebration of differences. (I remember one of his jokes about a yuppie in the Paris metro reading Anti-Oedipus as evidence.) In other words, the formal analogy - these political positions maintain the same geometry as capitalist ideology - is meant to undermine any pretensions to anti-capitalist or revolutionary positions. It seems to me the formal analogy doesn't determine anything.

HF: I don't know if it determines anything, but in certain contexts it might suggest something.

$\mathrm{MH}$ : Well, let's come back to the question of technologies. Often what we're really talking about when we talk about the politics of technology is formal arrangements. When we're talking about the internet, we are 
really about the image of a distributed network that is not able to be destroyed when any portion of it is destroyed. That's at least the story that's told about the DARPA development of the internet. It seems to me that that geometry can be used for radically different purposes, so what we have to really talk about is the uses of such machines not the machines themselves. This reminds me of a line in Volume 1 of Capital where Marx praises and criticizes the Luddites. He says they started attacking machines because the machines were the approximate image of their oppression, but it took them time to recognize that what they really needed to attack was not the machines but the social formation that employed those machines, that it wasn't the machines that were oppressing them but a social formation that had adopted them. That's the point I'm making here.

HF: The Communications Decency Act (1996), section $230 \mathrm{C1}$, has been in the news lately. Congress has been discussing revising or repealing 230 to hold online platforms accountable for facilitating criminal activity (such as sex trafficking and slavery etc.). So far 230 is still in place and platforms are not legally responsible for user content. The IT world doesn't want 230 knocked down because they think it will mean the end of internet freedom. Would this damage the internet as a potential "commons" (as you and Negri have the concept in your framework)? Or is this move against 230 an example of the opposite, of people acting to make the internet a common? (Or we could discuss Cambridge Analytica's use of Facebook data in the last election or the general "harvesting" of such data by various organizations.)

MH: I'm reluctant to think about the internet as a common space. It does seem to me a space like many other spaces in which the common could be constructed, but it's really in very large part a business opportunity. It's a sales environment. And so, it seems to me rather an extension of both capitalist markets and sometimes capitalist production networks rather than a space of the common.

HF: I agree.

$\mathrm{MH}$ : It could create a common framework and I think there are ways in which it does function now in this way, but in general it seems to me it doesn't. Net neutrality is partly about how businesses are regulated. There are questions about whether businesses ought to be held responsible for things that they facilitate or not. It's a little bit like the question of holding gun manufacturers responsible for killings done with their guns.

HF: I was thinking, with respect to net neutrality, the example you use in Assembly of the Google PageRank algorithm, of the way in which the internet produces "new subjectivities" through the perpetual incorporation of user preferences and data, which, in a series of recursive feedback loops, has greater influence on (helps to recreate) those user experiences and preferences.

MH: Yes. And even as a model of how platform capitalism in general extracts wealth from various social domains. So, already the metaphor of data mining might be a good way to start. There are some ways in which data mining is like real mining: wealth that's produced elsewhere ... Maybe part of what is necessary to consider (and maybe this will 
help us think differently about the real mining, too), is that the metaphor imagines that data is somehow inert and subjectless, whereas, in fact, data is already embedded in social relations. That might help us see how other forms of mining are in fact also embedded in social relations etc., and these substances are not inert objects.

What Toni and I mainly wanted to get to was a recognition of the structures of the extraction of wealth produced in social forms ... The Google PageRank algorithm is just an example of how that is accomplished; extraction does not take place only in the realm of minerals and petroleum. Our analysis of the PageRank algorithm was just a way of trying to work through that recognition.

HF: I agree that neither data nor minerals are inert. In the "machinic subjects" chapter of Assembly (2017, ch. 7), it almost seems that you suggest the internet could become a site for the positive production of new subjectivities which could turn against the means of their own production.

$\mathrm{MH}$ : I think I see what you mean. What would it mean to re-appropriate the algorithm? There was a slogan from industrial workers' movements of the 19th and 20th centuries that said, "Let's re-appropriate the machines." The whole notion of self-management in an industrial context functions with the imaginary that we can re-appropriate the machines and then deploy them differently in a different social relation. Let's try to build on that legacy today and ask: "What would it mean to re-appropriate the algorithm?" For instance, I was intrigued by a recent strike of Deliveroo drivers in Belgium. ${ }^{3}$ Deliveroo is a bicycle service bringing meals from restaurants. As with Uber, the deliverers are controlled by an algorithm. One of the demands of the Delieroo strike was that the deliverers wanted to control their algorithm, which seems like a really interesting way of posing the problem (Troncoso and Ciccarelli 2018). What if the Uber drivers - or the Amazon warehouse workers - were to demand control of their algorithm? Anyway, one recognizes that at least in these sectors of the economy, let's call it platform capitalism, control is conducted via algorithms. Instead of just opposing the machine (the algorithm, in this case), what would it mean to re-appropriate the machine and use it for different ends? Algorithms as such, being machines of recursive logics, don't have political content embedded within them.

Specific algorithms could have all kinds of embedded content. So, if the algorithmic machine in general doesn't necessarily come imbued with certain social contents, one could then ask about specific algorithms: Could they be transformed? In what ways? Are racial logics embedded within them? Could they be transformed? That's the kind of thing that people are working on.

\footnotetext{
${ }^{3}$ Deliveroo strikes continue around the world as of February 2019 (IWW 2019).
} 
HF: Even if we are already in a sense "machinic subjects" interwoven with tools of various kinds, given the way in which certain technologies (for example, let's say algorithms with intent) shape both our cultural consciousness and our individual synapses, shouldn't we be wary of - or at least far more careful about and critical of - their particular uses, given the power that they have to develop new subjectivities and new arenas for exploitation?

MH: I think we should be critical of them, and by critical here I partly mean being able to reveal and understand their functioning and uses. Absolutely. But not critical in the sense that we could hope to separate ourselves from them, because this would go against your first clause.

Here's the Spinozian version of the idea that we've always been machinic subjects - it's in the Treatise on the Emendation of the Intellect - which essentially says that from its beginnings, thought only functions through tools (Spinoza 1992). In the same way that by constructing physical tools we are able to make things more efficiently and make larger things, thought functions through the construction of tools. Thinking itself is inextricable from tools. It's just a matter of degree of different tools. Certainly, one should be critical of tools because there are good tools and bad tools, there are tools used for different ends. Digital tools, it seems to me, are not qualitatively different from non-digital tools.

HF: So, along these lines, one could say humans have always been machinic because our brains naturally create tools; logic makes us machines from the get-go. Does the collapse of this ontological divide (born and made, human and machine) go both ways? Humans in this formula are machinic but are machines subjects? Or does this undo the knot of subjectivity?

MH: I'm not saying that there aren't differences between humans and machines, but they do function through the similar mechanisms. We're all animals, for example, but that doesn't mean there's not a difference between dogs and humans.

So, the Spinozan line is that all of nature functions according to the same rules. There isn't a human nature that's separated from the rest of nature, there isn't an empire within an empire (that's his term for it), which doesn't mean that there aren't differences. There are differences. It's just that at a foundational level they function according to shared rules. That is the argument about machinic thought. There's another part of this argument that Toni and I make (Guattari is also intent on this): what is really machinic are assemblages, the ways in which disparate elements (human/nonhuman elements, animal nature, machines, etc.) function in coherent assemblages. These assemblages have elements that work together despite their internal diversity. 
HF: Stacy Alaimo (2010) makes a similar point in the idea of "transcorporeality": human bodies, of course, both comprise and are contained by ecosystems. Of course, not every "machine" in an assemblage contributes to its coherence or sustainability (toxins, for example, or, if you will, firstperson shooter games ...).

Sometimes, when a divide (for lack of a better word) between humans and the things that humans make is collapsed, a hidden Cartesian split is reinscribed. In some contexts, when humans become "machinic", the body is denigrated, and everything else is exteriorized into devices, digitized, etc. The most extreme version of this is the Transhumanist movement, with the goal of becoming downloadable consciousness, to exist in the "cloud," clones, or cyborgs. A lot of money and time is being invested in this enterprise (not to mention academic energy). ${ }^{4}$ It is a pathological dream of disembodiment, a solipsistic future in which humans (meaning, those few who can afford it) exist entirely in a world of their own making (an inevitably totalizing capitalism).

MH: So, in these versions the only part of the human that functions in a human machine/assemblage is the mental capacities. The corporeal capacities, you're saying, get dropped out and it's just the mind and the machine that function together.

That's a good point, but it doesn't have to be that way. There are notions of machinic assemblages that are strictly corporeal, as in the industrial factory. Emblematic for me is that first scene in Chaplin's Modern Times (1936) where his body becomes machinic.

HF: Yes, the Taylorist feeding machine. And then he goes up into the cogs.

$\mathrm{MH}$ : And I think in general the industrial paradigm of the factory as a great machine that uses workers rather than workers using a tool is a corporeal one. Anyway, I'm taking your point that it would be a danger if one were to think only about the mental capacities of the human as the relationship to the machine and leaving out the corporeal aspect.

HF: $\quad$ Recently Kim Stanley Robinson (2018) wrote in The Guardian, "Empty half the Earth of its humans. It's the only way to save the planet." Similarly, in his book on the Anthropocene, Timothy Clark (2015, 14-15) argues, "One definitive feature of the Anthropocene is the emergence of the human species per se as a different form of 'transpersonal agency'... The tragic danger at work in this new agency can be expressed in an image ... current humanity as a super-Leviathan." What is the relationship of the multitude to this view of population or this notion of the Anthropocene? You describe The Prince in Assem$b l y$, for example, as "a swarm, a multitude moving in coherent formation and carrying, implicitly, a threat” (Hardt and Negri 2017, xxi).

\footnotetext{
${ }^{4}$ For example, the new Penn State Journal of Posthuman Studies (see articles in 1(1) 2017).
} 
MH: I like that. Let me try to bring them together, because the two at least feel separate to start with. I think before treating the question of overpopulation one has to get out of the way the dominant framing of the question, which really is in racial terms (I'm not talking about Kim Stanley Robinson, but the conventional argument). Overpopulation has long been thought of primarily in terms of "dark" races that populate too much. And so, some people are really implying not just that we have too many people, but we have too many of those people. I'm not sure if it's in Malthus himself, but there's a long tradition starting in the nineteenth century that links discourses about overpopulation with racism and imperialism and discussions about sterilization.

HF: Yes. This is why it's the third rail of ecological and, indeed, left politics.

$\mathrm{MH}$ : For those reasons it should be a third rail, I mean, it should be a minefield. But once you address that my inclination is to think about population control in other terms, about reproduction rights, about other sorts of ways in which childbirth and child-rearing contributes to gender hierarchies, rather than in terms of the viability of the ecosystem of the planet.

Toni and I don't think of the multitude as an already existing subject or as an unorganized, spontaneous collection of people. I certainly agree with you that humanity as it is now has proven unable to act in the interest of the planet. We conceive the multitude instead as a political project, which must be organized. One component of that political project must be to create a new relationship to the earth.

Certain arguments within Anthropocene discourse or planetary destruction discourse claim that, because existing government structures have proven themselves incapable of addressing global warming and other forces of environmental destruction, we need a supranational and even global authority structure that has the capacity to force both nations and corporations to transform their practices and thus save the planet.

HF: And would this be a good thing?

MH: No. And I don't think it's a realistic goal, either. But it is symptomatic of not only the desperation of our situation but also the lack of political imagination.

HF: Gary Snyder has written that "ecology is a problem of love." I was thinking about your work on love, on the "power to be affected." Is there a connection between your work on love as a political project and love as an ecological necessity?

$\mathrm{MH}$ : That sounds nice. I don't have anything interesting to add, though. I can see the dots you're connecting with it; the question about love, the power to be affected, the inability to recognize the way that we are embedded within a global assemblage of human and nonhuman forces.

HF: You've put it in terms that seem to me to have ecological implications: "The more you are affected in many ways, the more alive you are, and to 
the extent you cease to be affected, to the extent you close off from the world, that much you die" $(2015,217)$.

$\mathrm{MH}$ : And that sounds nice. So, you're translating that, which seems to me an excellent way of doing it, into a recognition of the importance of human and nonhuman interconnectedness.

HF: Your move against property in the Empire books has the potential to connect many social and ecological movements. Would you care to discuss property and nonidentitarian politics?

$\mathrm{MH}$ : In thinking about the critique of property one has to think property in an expanded realm. So, it's not just a critique of the ownership of material goods. In fact, it might be useful to go back to the early modern notions of property that develop out of thinking about properties like your qualities, etc., and in some ways our modern notion of property grows out of that. I'm thinking of the C.B. MacPherson's The Political Theory of Possessive Individualism: Hobbes to Locke, but also The Passions and the Interests: Political Arguments for Capitalism before its Triumph by Albert Hirschman $(1977,1977)$. Both of them trace early modern conceptions of property and the way it develops. I'd be interested in a critique of property that extends to ... I was going to say cognates of property, but it's really other forms of property. For instance, the article by Cheryl Harris (1993) called "Whiteness as Property," in which she argues not just that whiteness gives access to property, but that whiteness itself is property, from the point of view of legal theory. In some ways it's a very short move from Cheryl Harris' argument to recognize identities and identity formations as property relations, so in that sense the critique of property has to involve an anti-identitarian political project. Hence, the abolition of private property and a nonidentitarian political formation have to go hand in hand. There are number of intermediating steps that I've alluded to but that seem not only a challenging but a promising, broad panorama.

HF: Finally, what do you think of the Rancière's (2009) remark that what is at stake in the definition of politics is "a struggle about what politics is, a struggle that is waged about such original issues as: 'where are we?', 'who are we?', 'what makes us a we', 'what do we see and what can we say about it that makes us a we, having a world in common?"'

$\mathrm{MH}$ : Yes, I do think that "we share a world in common." I identify this with something that I've liked in other of Rancière's works where the definition of politics is not a way of describing or redescribing what we already understand as politics. Rancière calls politics instead something actually quite narrow which doesn't encompass all the things that fall under the term today. In La Mésentente: Politique et Philosophies (1955, Éditions Galilée, [Dis-agreement: Politics and Philosophies]), politics is defined as the part (even thinking of it as the party) of those who have no part. And so, politics is really almost revolutionary struggle and nothing else. All these other things (for instance, what the media casually calls politics) - that's not politics, that's administration, that's police.

HF: So, real politics is revolutionary struggle against power that administers itself as politics. 
MH: Yes. Another description of the same thing might be what you just said, which is to discover a way of organizing the world that we share in common. That seems to me like an excellent prospect.

HF: Your work may not directly address the environmental crisis, but it is situated within a world in crisis. Does it share some of the forms and concerns of ecological critique?

$\mathrm{MH}$ : I want to start with two particularities to the notion of the common that might situate it within certain environmental discourses, beginning with the relatively simple definition of the common conceived primarily in contrast to property. Private or public, property is that which is characterized by exclusive rights to use and decision-making. In contrast to that, the common is defined by open access to use and democratic mechanisms of decision-making. Many people in different fields have contested the Garrett Hardin argument of "the tragedy of the commons" (1968). The common does have to be managed in some way, as Hardin says, but there aren't only two means to do it. Hardin's argument assumes that either private property or state control are required or the commons will be essentially unmanaged and go to ruin.

But there are other possible forms of management, democratic mechanisms for managing the common. And that's essentially where we're going with this. And once we conceive the common this way, we distinguish our argument from those contemporary arguments for the common that refer to an outside of capitalism, or a remaining function of pre-capitalist (and in that sense non-capitalist) institutions and relations. And so we - I realize this is something that works for me and Toni and may not be recognizable for others - are very consistent about using the term common rather than the commons because to our ears, the notion of the commons is a reference to a pre-capitalist social institution. When we refer to the common we're thinking of something that can be constructed from within capitalist society and from within capitalist relations to oppose them. The earth and its ecosystems can be made common. But we also think of the common as products of capitalist society: ideas, images, code, even forms of social cooperation. Nothing is automatically the common. It requires a political act to make it common.

HF: So, the common is always environment-plus-human. In other words, it's always a product of human interaction with the environment, conceived broadly.

$\mathrm{MH}$ : Yes, it is certainly that. And for me this topographical formulation is an important foundation for thinking about it, this continual reference to inside and outside. This is what distinguishes the way Toni and I think of the common from a number of other contemporary theorists of the commons (which seem to imagine the common as an outside to capital, and hence anti-capitalist in that way). But let me go back to your question. What is it in our work that forces us to open a discussion with and learn from ecological thinking? Our notion of the common does. 
HF: If the common is a political context of an assemblage of environment and human activity, what about the nonhuman in the common?

$\mathrm{MH}$ : It raises the question, "Is that democratic decision-making only human?" I cannot imagine a democratic decision-making structure that includes non-human agents, unless you are thinking of humans speaking for the nonhuman agents. Remember one of the axioms, or mandates, of liberation theory of the last thirty years is not to speak for others, not to speak in the name of others (though of course when Gayatri Spivak, Gilles Deleuze, Edward Said, and others said this they were thinking about other humans).

I don't understand what it could mean for nonhuman agents to make political decisions - and perhaps that shows the limits of my own political imagination. I also have a great deal of trouble thinking about the rights, even constitutional rights, of nature (such as the section about the rights of nature in the Ecuadorian constitution). I don't understand how nonhuman agents can be rightsbearing or how they can make political decisions. I am, instead, definitely attracted by forms of ecological thought framed in terms of relation rather than protection, and those that displace the subject-object framework.

So, we started with the notion that if we're going to understand the common as something that involves not only equal and open access for humans, but also democratic decision-making. The question is: Who counts as part of this democracy?

HF: Exactly, and both traditional notions of the commons (older ones, organic ones, those of the outside and/or outside capitalism) and your different notion of the common are always multispecies. For this reason, one must consider the historical and existing access of other agents.

$\mathrm{MH}$ : Okay. You mean with migration paths or something like that.

HF: Yes, that's one way to think of it. Much in the same way that keen British hikers will walk old paths through private property to maintain a public right of access, if humans really are one animal among many, then we must acknowledge the rights of access of other animals. This could become a first principle for democratic decision-making. In this way humans are not speaking for but with nonhuman others (with whom we have co-evolved) by acknowledging their basic need for, and so right of access to, clean air and water and land. We are not the only agents who have had our historical access to air, water, and land denied by capital.

$\mathrm{MH}$ : I like that. But, as I say, I continually run into the limits of my own political imagination. And I'm much more afraid than you are of anthropomorphism - that is, mistakenly projecting human qualities and abilities on to other species - especially when we are talking about politics.

HF: Frans de Waal distinguishes between "animalcentric anthropomorphism" and "anthropocentric anthropomorphism": "The first [makes every effort to take] the animal's perspective, the second takes ours. It 
is a bit like people we all know, who buy us presents that they think we like versus people who buy us presents that they like. The latter have not yet reached a mature form of empathy, and perhaps never will" (de Waal 2001, 77). He argues that if anthropomorphism is risky, "its opposite carries a risk too. To give it a name, I propose anthropodenial for the a priori rejection of shared characteristics between humans and animals when in fact they may exist" (2001, 68-69). While anthropodenial is still the default position of the sciences and the humanities, it may be a hard habit to maintain. As biologist Marc Bekoff writes of his colleagues,

I know no practicing researcher who doesn't attribute emotions to their companion animals - who doesn't freely anthropomorphize-at home or at cocktail parties, regardless of what they do at work. (This anthropomorphizing is nothing to be ashamed of, by the way... these scientists are simply doing what comes naturally. Anthropomorphizing is an evolved perceptual strategy; we've been shaped by natural selection to view animals in this way.) (Bekoff 2007, 10)

Just as our survival depends on the survival of a great many other creatures, it seems reasonable to assume this evolved capacity of anthropomorphism, and the biophilia it engenders, is necessary for human (and other animal) survival. Bekoff argues, "If we don't anthropomorphize, we lose important information ... it is a necessity, but it also must be done carefully, consciously, empathetically, and biocentrically. We must make every attempt to maintain the animal's point of view" (Bekoff 2007, 124-125). In short, difference exists along a continuum. I think it's always a mistake to assume that difference is some radical break across which we can't understand or empathize. Just as de Waal and Bekoff see animal-centric anthropomorphism as a starting point for good science, I'd argue it's a starting point for good politics.

MH: When talking about politics in a nonhuman or superhuman frame.

HF: Well, I would say politics as such has to be that now. If radical political theory does not try to think in an ecological frame, then it will miss the ground on which politics actually happens.

MH: I don't think I'm there. Politics, especially democratic politics, has a much higher threshold for expression and communication than what we are talking about here. I'm not saying it's not a good idea to think in this direction. My worry about anthropomorphism is a fear of misrecognition or a lessening of real difference - domesticating others and creating false representations of their desires and interests. That kind of situation is disastrous for politics.

HF: That's a very real fear, something we must keep in mind because it's always a risk - it's always a risk with other humans too, even ones as similar as we are (as two academics with shared interests, living in the same area, etc.). But communication and community-building involves risk. 
MH: Right. At least one of the points of Spivak's (1998) Can a Subaltern Speak? is that assuming that the subaltern can speak minimizes the difference and the conditions necessary for not only speaking but for their speech being recognized and understood. Wouldn't that increase a thousandfold when speaking across species? So, you're assuming that species can speak. And I'm sure they can speak. I'm not doubting they can speak, you know. It's the danger in the assumption that that speech could be understood and could function within a society of domination.

HF: Yes, I understand the problem. But there is another way to think about Spivak's basic point - that we must think about questions of agency in different and larger contexts, and that the political reality and implications of questions of agency and (self)representation do not disappear or dissipate with difficulty or difference (one might argue they increase). We live in a biotic polis. We share a world in common with other beings, which brings us back to your common.

$\mathrm{MH}$ Well, the common is [in this context] the opening that forces us to learn something new.

HF: I like that.

\section{Disclosure statement}

No potential conflict of interest was reported by the author.

\section{References}

Alaimo, Stacy. 2010. Bodily Natures: Science, Environment, and the Material Self. Bloomington: Indiana University Press.

Bekoff, Marc. 2007. The Emotional Lives of Animals. San Francisco, CA: New World Library.

Blanchot, Maurice. 1997. "The Apocalypse is Disappointing." In Friendship, translated by Elizabeth Rottenberg, 101-108. Stanford, CA: Stanford University Press.

Chaplin, Charlie. 1936. Modern Times. United Artists.

Clark, Timothy. 2015. Ecocriticism on the Edge: The Anthropocene as a Threshold Concept. London: Bloomsbury.

de Waal, Frans. 2001. The Ape and the Sushi Master: Cultural Reflections by a Primatologist. New York: Basic Books.

DiFranco, Ani. 2017. “My I.Q.,” Puddle Dive, Righteous Babe Records, January 30. Hardin, Garrett. 1968. "The Tragedy of the Commons." Science, December 13.

Hardt, Michael. 2010. “The Common in Communism.” Rethinking Marxism 22 (3): 346-356.

Hardt, Michael. 2012a. “Falsify the Currency!.” South Atlantic Quarterly 111 (2): 359379.

Hardt, Michael. 2012b. The Procedures of Love. Kassel. Germany: Documenta.

Hardt, Michael. 2015. "The Power to be Affected." International Journal of Politics, Culture and Society 28 (3): 215-222.

Hardt, Michael, and Antonio Negri. 2000. Empire. Cambridge, MA: Harvard University Press.

Hardt, Michael, and Antonio Negri. 2004. Multitude. London: Penguin. 
Hardt, Michael, and Antonio Negri. 2009. Commonweatlth. Cambridge: Harvard University Press.

Hardt, Michael, and Antonio Negri. 2017. Assembly. Oxford: Oxford University Press. Harris, Cheryl. 1993. "Whiteness as Property.” Harvard Law Review 106 (8): 17071794.

Hirschman, Albert. 1977. The Passions and the Interests:Political Arguments for Capitalism Before its Triumph. Princeton, NJ: Princeton University Press.

Horkheimer, Max, and Theodor Adorno. 2002. Dialectic of Enlightenment. Edited by Gunzelin Schmid Noerr. Translated by Edmund Jephcott. Stanford, CA: Stanford University Press.

IWW. 2019. "Deliveroo Strikes - Views from the Picket Line." IWW website, February 17. https://iww.org.uk/news/deliveroo-strikes-views-from-the-picketline/.

Jameson, Fred. 1979. "Reification and Utopia in Mass Culture." Social Text 1: 130148.

MacPherson, C. B. 1962. The Political Theory of Possessive Individualism: Hobbes to Locke. Oxford: Oxford University Press.

Rancière, Jacques. 1955. La Mésentente: Politique et Philosophies. Paris: Éditions Galilée.

Rancière, Jacques. 2009. "A Few Remarks on the Method of Jacques Rancière." Parallax 15 (3): 114-123.

Robinson, Kim Stanley. 2018. "Empty Half the Earth of its Humans. It's the Only Way to Save the Planet." The Guardian, March 20.

Spinoza, Benedictus de. 1992. The Ethics; Treatise on the Emendation of the Intellect. Edited by Seymour Feldman. Translated by Samuel Shirley. Indianapolis, IN: Hackett.

Spinoza, Benedictus de. 2007. Theological-Political Treatise. Edited by Jonathan Israel. Translated by Michael Silverthorne and Jonathan Israel. Cambridge: Cambridge University Press.

Spivak, Gayatri. 1998. Can the Subaltern Speak? New York: Macmillan.

Troncoso, Stacco, and Roberto Ciccarelli. 2018. "Workers Are the Heart of the Algorithm." Commons Film, January 29. http://commonsfilm.com/2018/01/29/ workers-are-the-heart-of-the-algorithm/.

Žižek, Slavoj. 2006. The Parallax View. Cambridge: MIT. 